\title{
CSMD1 wt Allele
}

National Cancer Institute

\section{Source}

National Cancer Institute. CSMD1 wt Allele. NCI Thesaurus. Code C88932.

Human CSMD1 wild-type allele is located in the vicinity of 8p23.2 and is approximately 2,059 kb in length. This allele, which encodes CUB and sushi domain-containing protein 1, may be involved in the modulation of complement. Mutation or deletion of the gene is associated with invasive ductal breast carcinoma, colorectal adenocarcinoma and head and neck carcinomas. 